\title{
Analysis of The Use of Sawdust Waste As Concrete Mixture Add Material Against Workability and Compressive Strength Concrete With Three Concrete Treatment Methods
}

\author{
Syafwandi", Danu Setyo Sembodo, Agyanata Tua Munthe, Agung Sumarno \\ Faculty of Engineering, Mercu Buana University, Jakarta, Indonesia \\ *Corresponding author E-mail: wandi.syaf@gmail.com
}

Manuscript received 23 Feb 2021; revised 2 March. 2021; accepted 15 March 2021. Date of publication 2 April 2021

\begin{abstract}
Wood management activities that are often encountered, as in wood cutting activities in the manufacture of wooden handicrafts, basically after this activity can become a problem, namely sawdust waste, where this waste if left for so long will be a big problem and have an impact on the environment. One solution that can be used for the problem of sawdust waste is to mix this sawdust waste into a concrete mixture. This sawdust waste can be used in concrete mixtures because of the cellulose content in sawdust waste which can affect the compressive strength value with different concrete treatment methods (curing) and slump of concrete. In this research included into experimental research with wood used is wood kamper samarinda, from the leftover cutting of wood frames from craftsman wood UD. kembang Arum in Bekasi, West Java. Using sawdust waste with a size that passes through sieve No.4 (passes through a $4.75 \mathrm{~mm}$ ) with variaes addition of $0 \mathrm{~kg} / \mathrm{m} 3,1 \mathrm{~kg} / \mathrm{m} 3$ dan $1,5 \mathrm{~kg} / \mathrm{m} 3$, as well as testing with a concrete mixture that has a mix design of $35 \mathrm{MPa}$ f'c which is inserted into the test object in the form of a cylinder with a diameter and height of 15 and $30 \mathrm{~cm}$ which is then for the treatment method done by three different methods. The addition of saw dust waste with a varies of $1 \mathrm{~kg} / \mathrm{m} 3 \mathrm{dan} 1,5 \mathrm{~kg} / \mathrm{m} 3$ to the concrete mixture makes the slump and workability values decrease, but the slump value obtained is still in accordance with slump value plan. and for compressive strength values with an addition variation of $1 \mathrm{~kg} / \mathrm{m} 3$ and $1.5 \mathrm{~kg} / \mathrm{m} 3$, The compressive strength value changes from the normal compressive strength value of concrete and the effect of the treatment method also affects the compressive strength value obtained.
\end{abstract}

Keywords: Saw Dust, Workability, Concrete Compressive Strength, Three Method Treatment.

\section{Introduction}

The growth of technology and needs in this day and age is in line with the development of the construction world that continu es to find new ideas and innovations such as the form of structural dimensions, working methods or materials in the formation of a concrete [1]. In the world of construction is always identical with of concrete and concrete is a component of the main or important structure of a construction building. concrete is a mixture consisting of portland cement or other hydraulic cement, sand, split stone, or other argegat argegat with or without additional materials (admixture). Concrete has good compressive strength, therefore concrete is widely used or used for construction building needs [2] [3].

Innovation and technological advances, especially in concrete technology has grown rapidly where this effort aims to find something new in order to get better quality concrete than before [4]. All matters previously researched are intended to solve problems that arise both in concrete forming materials and materials, the use of residual materials or constraints arising from implementation activities as long as concrete is made until ready for use. This problem is what makes an innovation or new findings very necessary and the answer to the problem [5] [6].

The use of fiber in concrete mixture has been done long enough, but because the availability is decreasing, various types are developed, one of which is wood fiber. Wood is one of the materials with a very high cellulose content of $72 \%$. In addition to cellulose, wood powder also contains hemicellulose levels, in general biomass also contains lignin in an amount of about 15-30\% dry weight of the material [7]. Wood powder waste is a waste from the results of wood cutting aktififas that are often found in wood management plants or wood craftsmen [8]. Until now, the management of wood powder waste can be said to have not been optimal in part only designation as a material for compost fertilizer and more often found this wood powder waste is burned or discarded because wood powder is considered to have no economic value and is only considered as industrial waste only. if waste is disposed of continuously in the absence of maximum treatment 
can cause balance disorders, thereby causing the environment not functioning as before in the sense of health, welfare and biological safety [9] [10].

The need for clean water that is qualified in its designation has begun to decrease and difficult to find, especially in large cities and neighborhoods in residents who find it difficult to find clean water in addition to the use of clean water is prioritized for primary needs only. In the future fresh water will be very difficult to find because the world's freshwater content is currently experiencing a very drastic reduction, which will greatly affect the implementation process of development in the field of civil engineering, especially the concrete curing process [11] [12].

Concrete maintenance (curing) is an activity carried out after the concrete reaches the final setting time and has the aim to keep the concrete from losing water quickly and also maintain the temperature or humidity of the concrete to achieve the planned concrete quality value [13] [14].

\section{Methods}

The method used is experimental with grooves (see figure 1), this research begins with preparing the necessary materials and tools. The tool that will be used in the research must be in good condition and has been calibrated before to avoid any errors in the research, then continued by conducting testing on matrial materials and continued with the planning of the design mix calculation that refers to (SNI 032834-2000). Then do trial mix, slump test, after that done concrete attachment using cylinders, After the life of concrete for 24 hours then the concrete will be opened from the mold and continued with doing concrete maintenance activities (curing). After the treatment method has been done, then the strong press process will be carried out in accordance with the age of concrete to be examined, namely at the planned concrete age.

In this study using additional materials in the form of sawdust waste with the addition of as much as $0 \mathrm{~kg} / \mathrm{m} 3,1 \mathrm{~kg} / \mathrm{m} 3 \mathrm{dan} 1,5 \mathrm{~kg} / \mathrm{m} 3$ added to the concrete mixture with the quality of F'c $35 \mathrm{MPa}$ for jumah sample needs and material needs (see tables 1 and 2), in addition this research will also be tested using three treatment methods, namely soaking treatment methods test objects, closing test objects with gunny sacks and with a high temperature of $87.5^{\circ} \mathrm{C}$

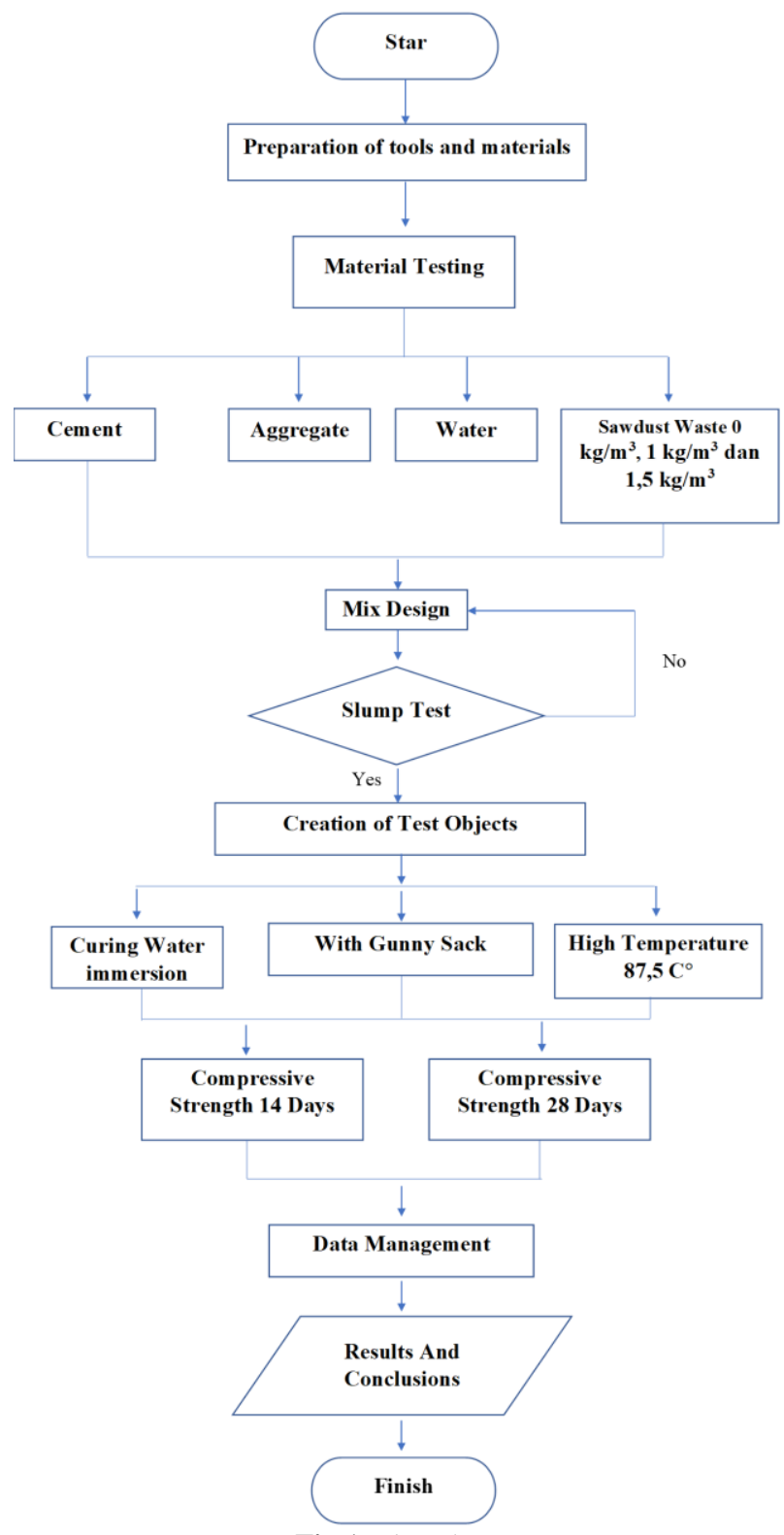

Fig 1. Flowchart

source : Research Data 
Table 1. Number of Samples Needed

\begin{tabular}{|c|c|c|c|c|}
\hline \multicolumn{5}{|c|}{ Sample Needs } \\
\hline \multirow[t]{2}{*}{ Name } & \multirow[t]{2}{*}{ Sample } & Soaking Water & Gunny Sack & $\begin{array}{c}\text { High Temperature } \\
87,5 \mathrm{C} \\
\end{array}$ \\
\hline & & \multicolumn{3}{|c|}{14 Days } \\
\hline Normal Concrete & $\mathrm{BN}$ & 3 & 3 & 3 \\
\hline $\begin{array}{l}\text { Concrete }+1 \mathrm{~kg} / \mathrm{m}^{3} \\
\text { Sawdust Waste }\end{array}$ & BSK 1 & 3 & 3 & 3 \\
\hline $\begin{array}{l}\text { Concrete }+1,5 \mathrm{~kg} / \mathrm{m}^{3} \\
\text { Sawdust Waste }\end{array}$ & BSK 2 & 3 & 3 & 3 \\
\hline \multicolumn{5}{|c|}{ Sample Needs } \\
\hline \multirow[t]{2}{*}{ Name } & \multirow{2}{*}{ Sample } & Soaking Water & Gunny Sack & $\begin{array}{c}\text { High Temperature } \\
87,5 \mathrm{C}\end{array}$ \\
\hline & & \multicolumn{3}{|c|}{28 Days } \\
\hline Normal Concrete & $\mathrm{BN}$ & 3 & 3 & 3 \\
\hline $\begin{array}{l}\text { Concrete }+1 \mathrm{~kg} / \mathrm{m}^{3} \\
\text { Sawdust Waste }\end{array}$ & BSK 1 & 3 & 3 & 3 \\
\hline $\begin{array}{l}\text { Concrete }+1,5 \mathrm{~kg} / \mathrm{m}^{3} \\
\text { Sawdust Waste }\end{array}$ & BSK 2 & 3 & 3 & 3 \\
\hline
\end{tabular}

Table 2. Material Needs for $1 \mathrm{~m}^{3}$ quality F'c $35 \mathrm{MPa}$

\begin{tabular}{|l|c|c|c|c|c|c|}
\hline \multicolumn{7}{|c|}{ Material Needs for $1 \mathrm{~m}^{3}$} \\
\hline Name & $\begin{array}{c}\text { Sampel } \\
(\mathrm{Kg})\end{array}$ & $\begin{array}{c}\text { Cement } \\
(\mathrm{Kg})\end{array}$ & Split $(\mathrm{Kg})$ & $\begin{array}{c}\text { Sand } \\
(\mathrm{Kg})\end{array}$ & $\begin{array}{c}\text { Water } \\
(\mathrm{Kg})\end{array}$ & $\begin{array}{c}\text { Sawdust } \\
(\mathrm{Kg})\end{array}$ \\
\hline Normal Concrete & BN & 407,5 & 1090,44 & 697,16 & 184,9 & 0 \\
\hline $\begin{array}{l}\text { Concrete }+1 \mathrm{~kg} / \mathrm{m}^{3} \\
\text { Sawdust Waste }\end{array}$ & BSK 1 & 407,5 & 1090,44 & 697,16 & 184,9 & 1 \\
\hline $\begin{array}{l}\text { Concrete }+1,5 \mathrm{~kg} / \mathrm{m}^{3} \\
\text { Sawdust Waste }\end{array}$ & BSK 2 & 407,5 & 1090,44 & 697,16 & 184,9 & 1,5 \\
\hline
\end{tabular}

Place : Dynamix Laboratory Bogor, West Java Indonesia

Time : December 2020 - January 2021

\section{Results and Discussion}

\subsection{Gradation Analysis of split stone}

The analysis of split stone gradation aims to find out the size of the grain and the order of grains of the coarse argegat based on the sieve number, so that it can obtain the value of the smoothness modulus. The following gradient values are underestimated (See table 3 ) :

Table 3. Value of Gradation Split Stone (Method ASTM C136)

\begin{tabular}{|c|c|c|c|c|c|}
\hline \multicolumn{5}{|c|}{ Analysis Gradation Split } \\
\hline \multicolumn{2}{|c|}{ Source } & \multicolumn{5}{c|}{ Maloko } \\
\hline \multicolumn{2}{|c|}{ ASTM SIEVE } & $\begin{array}{c}\text { Weight } \\
\text { Retained }\end{array}$ & $\begin{array}{c}\text { Accumul } \\
\text { Retained }\end{array}$ & $\begin{array}{c}\text { accumul } \\
\text { Weight }\end{array}$ & Passing \\
\hline Inchi/No & $\mathrm{mm}$ & $(\mathrm{gr})$ & $(\mathrm{gr})$ & $(\%)$ & $(\%)$ \\
\hline $1,5^{\prime \prime}$ & 37,5 & 0 & 0 & $0,0 \%$ & $100,0 \%$ \\
\hline $1 "$ & 25 & 25 & 25 & $1,7 \%$ & $98,3 \%$ \\
\hline $3 / 4^{\prime \prime}$ & 19 & 456 & 481 & $32,1 \%$ & $67,9 \%$ \\
\hline $1 / 2^{\prime \prime}$ & 12,5 & 813 & 1294 & $86,3 \%$ & $13,7 \%$ \\
\hline $3 / 8^{\prime \prime}$ & 9,50 & 184 & 1478 & $98,5 \%$ & $1,5 \%$ \\
\hline 4 & 4,75 & 11 & 1489 & $99,3 \%$ & $0,7 \%$ \\
\hline 8 & 2,36 & 0 & 1489 & $99,3 \%$ & $0,7 \%$ \\
\hline 16 & 1,18 & 0 & 1489 & $99,3 \%$ & $0,7 \%$ \\
\hline 30 & 0,600 & 0 & 1489 & $99,3 \%$ & $0,7 \%$ \\
\hline 50 & 0,3 & 0 & 1489 & $99,3 \%$ & $0,7 \%$ \\
\hline 100 & 0,15 & 0 & 1489 & $99,3 \%$ & $0,7 \%$ \\
\hline 200 & 0,075 & 0 & 1489 & $99,3 \%$ & $0,7 \%$ \\
\hline Pan & \multicolumn{7}{|c|}{ FM } & 11 & 1500 & $100,0 \%$ & $0,0 \%$ \\
\hline \multicolumn{7}{|c|}{} \\
\hline
\end{tabular}

$F M=\frac{\text { Comulative } \text { weight restrained }(\%)}{20}$

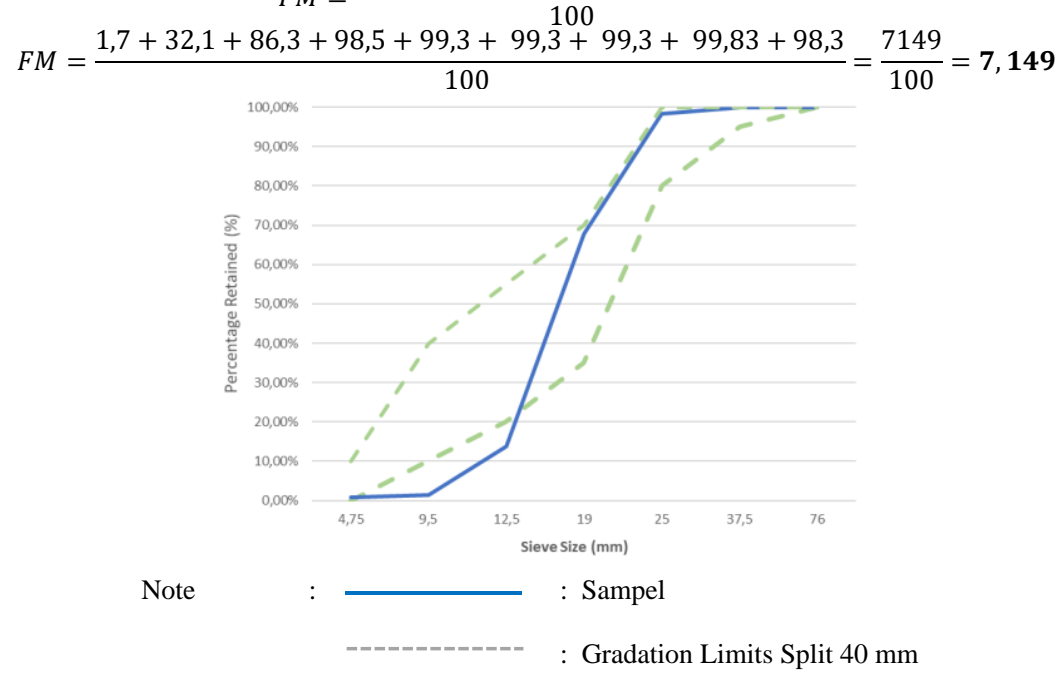

Fig 2. Graph of Split Stone Gradation Analysis 
From the FM value obtained by 7,149 where the requirement of 6- 7.1 ( SK SNI S 04-1898-F : 29) and can be declared granules greater than the standard at the maximum diameter of argegat rough, the enis argegat used with a maximum size is $40 \mathrm{~mm}$.

\subsection{Gradation Analysis of Sand}

Gradation analysis of sand aims to find out the size of granules and the composition of grains (gradation) of fine argegat according to the number of sieves, so as to determine the modulus value of sand smoothness in this study. Here are the values obtained in the sand gradation test :

Table 4. Value of Gradation Sand Balitung (Method ASTM C136)

\begin{tabular}{|c|c|c|c|c|c|}
\hline \multicolumn{5}{|c|}{ Analysis Gradation Sand } \\
\hline Source & \multicolumn{5}{|c|}{ PAP - Balitung } \\
\hline \multicolumn{2}{|c|}{ ASTM SIEVE } & Weight Retained & Accumul Retained & $\begin{array}{c}\text { accumul } \\
\text { Weight }\end{array}$ & Passing \\
\hline Inchi/No & $\mathrm{mm}$ & $(\mathrm{gr})$ & $(\mathrm{gr})$ & $(\%)$ & $(\%)$ \\
\hline $3 / 8^{\prime \prime}$ & 9,5 & 3 & 3 & $0,2 \%$ & $99,8 \%$ \\
\hline 4 & 4,75 & 31 & 34 & $2,3 \%$ & $97,7 \%$ \\
\hline 8 & 2,36 & 114 & 148 & $9,9 \%$ & $90,1 \%$ \\
\hline 16 & 1,18 & 307 & 455 & $30,3 \%$ & $69,7 \%$ \\
\hline 30 & 0,60 & 272 & 727 & $48,5 \%$ & $51,5 \%$ \\
\hline 50 & 0,30 & 322 & 1049 & $69,9 \%$ & $30,1 \%$ \\
\hline 100 & 0,15 & 219 & 1268 & $84,5 \%$ & $15,5 \%$ \\
\hline 200 & 0,075 & 160 & 1428 & $95,2 \%$ & $4,8 \%$ \\
\hline \multicolumn{7}{|c|}{ Pan } & 72 & 1500 & $100,0 \%$ & $0,0 \%$ \\
\hline \multicolumn{7}{|c|}{ FM } & & $\mathbf{2 , 4 5 6}$ \\
\hline
\end{tabular}

$$
\begin{gathered}
F M=\frac{\text { Comulative weight restrained (\%) }}{100} \\
F M=\frac{0,2+2,3+9,9+30,3+48,5+69,9+84,5}{100}=\frac{2456}{100}=\mathbf{2 , 4 5 6}
\end{gathered}
$$

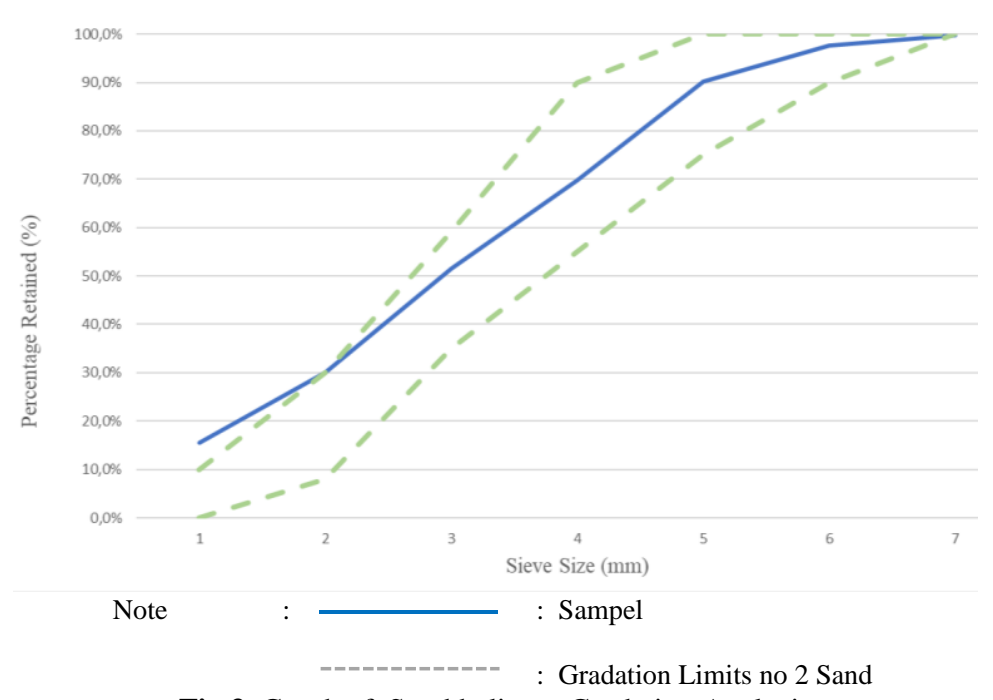

Fig 3. Graph of Sand balitung Gradation Analysis

From the FM value obtained by 2,456 where the requirements are in accordance with the standard sand group gradation group no. 2 of 1.5-3.8 (SK SNI S 04-1898-F : 29).

\subsection{Specific Gravity, Absorption and Sludge Levels}

The value of specific gravity, absorption and mud content (see table 5) obtained where for split specific gravity obtained 2,61 gr/ $\mathrm{cm}^{3}$, absorption $2.25 \%$ and sludge levels of $0.73 \%$ then for sand specific gravity obtained $2,6 \mathrm{gr} / \mathrm{cm}^{3}$, absorption $2.67 \%$ and sludge levels of $4.8 \%$, sludge levels obtained for both materials in accordance with the rules (SK SNI S 04-1898-F : 29) where for coarse argegat below $1 \%$ and for fine argegat below $5 \%$ so that the material can be used.

Table 5. Testing Results of specific gravity, Absorption and Sludge Levels

\begin{tabular}{ccc}
\hline Testing & Split & Sand \\
\hline Specific Gravity & $2,61 \mathrm{gr} / \mathrm{cm}^{3}$ & $2,6 \mathrm{gr} / \mathrm{cm}^{3}$ \\
\hline Absorption & $2,25 \%$ & $2,67 \%$ \\
\hline Sludge Levels & $0,73 \%$ & $4,8 \%$ \\
\hline
\end{tabular}




\subsection{Testing Workability Concrete}

This study aims to find out the effect of adding sawdust waste to the workability concrete, in this study the value of slump plan specified is \pm 12 , from the experiments that have been done slump value obtained as follows (see table 6 ) :

Tabel 6. Testing Workability Concrete Value

\begin{tabular}{ccc}
\hline \multicolumn{2}{c}{ Slump Value } \\
\hline TM 1 - Sawdust 0 Kg/m3 & TM 2 - Sawdust 1Kg/m3 & TM 3 - Sawdust 1,5 Kg/m3 \\
\hline $13,8 \mathrm{~cm}$ & $12,9 \mathrm{~cm}$ & $10,2 \mathrm{~cm}$ \\
\hline
\end{tabular}

From the experiments that have been done slump value obtained that normal concrete in the absence of additional Sawdust waste get a slump value of $13.8 \mathrm{~cm}$, and for the addition of wood powder waste as much as $1 \mathrm{~kg} / \mathrm{m}^{3}$ and $1,5 \mathrm{~kg} / \mathrm{m}^{3}$ get a slump value of $12.9 \mathrm{~cm}$ and $10.2 \mathrm{~cm}$, respectively. from the results of the experiments carried out the value of the slump is still in the value of the slump plan.

\subsection{Concrete Compressive Strength}

Compressive Strength on this research beforehand through the concrete treatment stage, where in this research using three different concrete treatment methods; concrete press strength results obtained as follows (see tables 7,8 and 9)

1. Compressive Strength With Water Soak treatment Method

Table 7. Value Compressive Strength With Water Soak treatment Method

\begin{tabular}{|c|c|c|c|c|}
\hline \multicolumn{5}{|c|}{ Compressive Strength With Water Soak treatment Method (MPa) } \\
\hline \multicolumn{2}{|c|}{ Sawdust Waste } & $0 \mathrm{~kg} / \mathrm{m}^{3}$ & $1 \mathrm{~kg} / \mathrm{m}^{3}$ & $1,5 \mathrm{~kg} / \mathrm{m}^{3}$ \\
\hline 14 Days & 1 & 26,12 & 24,08 & 27,93 \\
\hline \multirow[t]{2}{*}{$(\mathrm{MPa})$} & 2 & 27,32 & 27,33 & 27,93 \\
\hline & 3 & 28,00 & 26,00 & 25,03 \\
\hline Average & & 27,15 & 25,80 & 26,96 \\
\hline \multicolumn{2}{|c|}{ Increase in Quality (\%) } & $0,00 \%$ & $-4,95 \%$ & $-0,68 \%$ \\
\hline 28 Days & 1 & 37,96 & 34,23 & 37,04 \\
\hline \multirow[t]{2}{*}{$(\mathrm{MPa})$} & 2 & 36,06 & 35,60 & 36,51 \\
\hline & 3 & 34,00 & 37,52 & 35,50 \\
\hline Averege & & 36,01 & 35,78 & 36,35 \\
\hline \multicolumn{2}{|c|}{ Increase in Quality (\%) } & $0,00 \%$ & $-0,62 \%$ & $0,95 \%$ \\
\hline
\end{tabular}

2. Compressive Strength With Gunny Sacks Treatment Method

Tabel 8. Value Compressive Strength With Gunny Sacks Treatment Method

\begin{tabular}{|c|c|c|c|c|}
\hline \multicolumn{5}{|c|}{ Compressive Strength With Gunny Sacks Treatment Method (MPa) } \\
\hline \multicolumn{2}{|c|}{ Sawdust Waste } & $0 \mathrm{~kg} / \mathrm{m}^{3}$ & $1 \mathrm{~kg} / \mathrm{m}^{3}$ & $1,5 \mathrm{~kg} / \mathrm{m}^{3}$ \\
\hline 14 Days & 1 & 24,66 & 22,64 & 25,02 \\
\hline \multirow[t]{2}{*}{ (MPa) } & 2 & 26,81 & 21,19 & 22,39 \\
\hline & 3 & 27,01 & 23,20 & 25,00 \\
\hline Average & & 26,16 & 22,34 & 24,14 \\
\hline \multicolumn{2}{|c|}{ Increase in Quality (\%) } & $0,00 \%$ & $-14,11 \%$ & $-7,44 \%$ \\
\hline 28 Days & 1 & 34,89 & 32,68 & 33,20 \\
\hline \multirow[t]{2}{*}{ (MPa) } & 2 & 33,26 & 32,00 & 32,00 \\
\hline & 3 & 35,10 & 31,50 & 33,04 \\
\hline Averege & & $\mathbf{3 4 , 4 2}$ & 32,06 & 32,75 \\
\hline \multicolumn{2}{|c|}{ Increase in Quality (\%) } & $0,00 \%$ & $-6,85 \%$ & $-4,85 \%$ \\
\hline
\end{tabular}

3. Compressive Strength With Treatment Method a high temperature $87,5 \mathrm{C}^{\circ}$

Tabel 9. Value Compressive Strength With Treatment Method High Temperature 87,5 $\mathrm{C}^{\circ}$

\begin{tabular}{|c|c|c|c|c|}
\hline \multicolumn{5}{|c|}{ Compressive Strength With Treatment Method High Temperature 87,5 $\mathrm{C}^{\circ}(\mathrm{MPa})$} \\
\hline \multicolumn{2}{|c|}{ Sawdust Waste } & $0 \mathrm{~kg} / \mathrm{m}^{3}$ & $1 \mathrm{~kg} / \mathrm{m}^{3}$ & $1,5 \mathrm{~kg} / \mathrm{m}^{3}$ \\
\hline 14 Days & 1 & 22,38 & 22,22 & 22,19 \\
\hline \multirow[t]{2}{*}{ (MPa) } & 2 & 24,31 & 22,77 & 22,10 \\
\hline & 3 & 25,50 & 22,50 & 21,30 \\
\hline Average & & 24,06 & $\mathbf{2 2 , 5 0}$ & 21,87 \\
\hline \multicolumn{2}{|c|}{ Increase in Quality (\%) } & $\mathbf{0 , 0 0 \%}$ & $-6,51 \%$ & $-9,13 \%$ \\
\hline 28 Days & 1 & 30,09 & 30,06 & 29,91 \\
\hline \multirow[t]{2}{*}{$(\mathrm{MPa})$} & 2 & 29,00 & 28,50 & 29,85 \\
\hline & 3 & 31,90 & 30,60 & 28,95 \\
\hline Averege & & $\mathbf{3 0 , 3 3}$ & 29,72 & 29,57 \\
\hline \multicolumn{2}{|c|}{ Increase in Quality (\%) } & $0,00 \%$ & $-2,01 \%$ & $-2,01 \%$ \\
\hline
\end{tabular}


Table 10. Value Concrete Compressive Strength

\begin{tabular}{|c|c|c|c|c|c|c|}
\hline $\begin{array}{c}\text { Sawdust } \\
\text { Waste }\end{array}$ & \multicolumn{2}{|c|}{$\begin{array}{c}\text { Compressive } \\
\text { Strength With Water } \\
\text { Soak treatment } \\
\text { Method (MPa) }\end{array}$} & \multicolumn{2}{|c|}{$\begin{array}{c}\text { Compressive Strength } \\
\text { With Gunny Sacks } \\
\text { Treatment Method } \\
\text { (MPa) }\end{array}$} & \multicolumn{2}{|c|}{$\begin{array}{c}\text { Compressive Strength } \\
\text { With Treatment Method } \\
\text { High Temperature 87,5 } \\
\text { C }\end{array}$} \\
\hline Variation & 14 Days & 28 Days & 14 Days & 28 Days & 14 Days & 28 Days \\
\hline $0 \mathrm{~kg} / \mathrm{m} 3$ & $\mathbf{2 7 , 1 5}$ & $\mathbf{3 6 , 0 1}$ & $\mathbf{2 6 , 1 6}$ & $\mathbf{3 4 , 4 2}$ & $\mathbf{2 4 , 0 6}$ & $\mathbf{3 0 , 3 3}$ \\
\hline $1 \mathrm{~kg} / \mathrm{m} 3$ & $\mathbf{2 5 , 8 0}$ & $\mathbf{3 5 , 7 8}$ & $\mathbf{2 2 , 3 4}$ & $\mathbf{3 2 , 0 6}$ & $\mathbf{2 2 , 5 0}$ & $\mathbf{2 9 , 7 2}$ \\
\hline $1,5 \mathrm{~kg} / \mathrm{m} 3$ & $\mathbf{2 6 , 9 6}$ & $\mathbf{3 6 , 3 5}$ & $\mathbf{2 4 , 1 4}$ & $\mathbf{3 2 , 7 5}$ & $\mathbf{2 1 , 8 7}$ & $\mathbf{2 9 , 5 7}$ \\
\hline
\end{tabular}

Compressive Strength value obtained (see table 10), Compressive Strength value on concrete with added material of $1,5 \mathrm{~kg} / \mathrm{m}^{3}$ with the method of soaking test object into water get the best hard press value while getting an increase in the press strength value of normal concrete or concrete in the absence of added material of $0,34 \mathrm{MPa}$ or an increase of $0,95 \%$, in addition to the strong value of press with the addition of wood powder waste as much as $1 \mathrm{~kg} / \mathrm{m}^{3}$ Compressive Strength value tends to fall and generally has a lower pressure strength value of all variations and on existing treatment methods except in curing methods at high temperatures, there are several factors that can be the basis of why this can happen one of which is the addition of wood powder waste that is too fine so that it affects the percentage of fine argegat on concrete mixtures and for the case of the addition of strong value press that occurs this can occur due to the presence of compounds in wood powder waste, especially cellulose that provides bonding strength between particles so that the strong value of the press that occurs can increase. Then for the use of curing method or treatment with high temperature strong value press tends to continuously decrease with the addition of wood powder waste this indicates that the addition of wood powder waste in concrete treatment conditions with a high temperature of $87,5 \mathrm{C}^{\circ}$ is not suitable it is also strengthened because cellulose compounds in wood waste at high temperatures lose their atoms, especially the $\mathrm{OH}$ tied to cellulose so that cellulose will lose hydrogen and oxygen so that it leaves only carbon compounds in it, therefore the addition of wood powder waste added materials to high temperature treatment methods only gives an adverse impact to the press strength of concrete.

\section{Conclusion}

Based on the results of testing and research that has been done on the effect of adding Sawdust waste to the value of workability and Compressive Strength with three conditions of concrete maintenance, a conclusion was obtained as follows:

1. The value of workability obtained by the addition of sawdust waste produces a workability value lower than concrete without the addition of sawdust waste in other words in theory justifies that the cellulose content in sawdust waste provides additional value of connective strength between particles due to the adhesion properties (interesting tensile properties between molecules are not similar). However, the value of workability obtained is still in accordance with the planned workability value of $12 \pm 2 \mathrm{~cm}$.

2. Compresive streangth value of press in this study can be concluded that the addition of wood powder waste in concrete mixture affects the existing strong press value where the result obtained strong value of press increases in quality, especially for the addition of 1,5 $\mathrm{Kg} / \mathrm{m}^{3}$ with the method of soaking test objects into water while for the addition of wood powder waste with other treatment methods the strong value of press tends to decrease.

3. For other testing with variations of addition and method of concrete treatment of Compresive streangth value obtained differently where with the method of soaking concrete test object into water get good value while for the method of closing test objects with gunny sacks strong value of concrete press decreased from the previous method and for treatment methods with high temperature, the quality of concrete obtained experienced a very cyclical decrease from other concrete treatment methods in this research..

\section{References}

[1] A. H. Ujang, A. R. Omar, I. A. Rani, A. Azmi, S. B. M. Kamal, and D. Abdullah, "Factors Influencing Consumer's Intention to use Self Service Technology in Tourism and Hospitality Industry," Int. Acad. Res. J. Bus. Technol., 2016.

[2] S. Azhar, W. A. Carlton, D. Olsen, and I. Ahmad, "Building information modeling for sustainable design and LEED ® rating analysis," Autom. Constr., 2011, doi: 10.1016/j.autcon.2010.09.019.

[3] M. D. Martínez-Aires, M. López-Alonso, and M. Martínez-Rojas, "Building information modeling and safety management: A systematic review," Safety Science. 2018, doi: 10.1016/j.ssci.2017.08.015.

[4] C. Drive et al., "Experiences from recent European research projects on the interplay between technology and design," Mater. Des., 2007.

[5] R. Han, Z. Feng, X. Fan, T. Xu, J. Tian, and J. Meng, "A new intelligent VR biological learning system based on natural interaction," Proc. 2020 IEEE 4th Inf. Technol. Networking, Electron. Autom. Control Conf. ITNEC 2020, no. Itnec, pp. 175-179, 2020, doi: 10.1109/ITNEC48623.2020.9085016.

[6] D. Oktavia, M. M. E. I. Bali, H. Rahman, U. Umar, A. Syakroni, and F. Widat, "Exploration of Fine Motor Skills through the Application of Paint," in WESTECH, 2019, pp. 1-6, doi: 10.4108/eai.8-12-2018.2284038.

[7] H. Susanto, "'Pengembangan proses pemisahan furfural dari black liquor pemasakan tandan kosong sawit dalam pelarut organik"," 1998.

[8] P. Barbaro et al., "Safety Data Sheet," J. Am. Chem. Soc., 2009, doi: 10.1021/jm701266y.

[9] Danusaputro, Hukum Lingkungan. Bina Cipta, 1978.

[10] H. F. Hansen and O. Rieper, "The evedence movement: The development and consequences of methodologies in review practices," Evaluation, 2009, doi: 10.1177/1356389008101968.

[11] D. Handayani and A. Purwanto, "Penilaian Risiko Keselamatan Dan Kesehatan Kerja," Din. Rekayasa, 2014.

[12] M. Safiuddin, M. A. Salam, and M. Z. Jumaat, "Utilization of palm oil fuel ash in concrete: A review," Journal of Civil Engineering and Management. 2011, doi: 10.3846/13923730.2011.574450.

[13] M. W. Choirul Umam, F. Hardaningrum, and R. Durrotun Nasihien, "Analysis Of Traffic Accident Area On The Road In Gresik District Based On Geographic Information System,” Int. J. Eng. Sci. Inf. Technol., vol. 1, no. 2, 2021, doi: 10.52088/ijesty.v1i2.52.

[14] R. Y. Widya Baskara, A. Wahyuni, and F. Hardanignrum, "The Effect Of Road Narrowing On The Traffic Characteristics," Int. J. 
Eng. Sci. Inf. Technol., vol. 1, no. 2, 2021, doi: 10.52088/ijesty.v1i2.54.

[15] SNI 03-2834-2000, "SNI 03-2834-2000: Tata cara pembuatan rencana campuran beton normal," Sni 03-2834-2000, pp. 1-34, 2000.

[16] Departemen Pekerjaan Umum, SK SNI S-04-1989-F : Spesifikasi Bahan Bangunan Bagian A (Bahan Bangunan Bukan Logam). Bandung: Yayasan LPMB, 1989. 